\title{
Prophet Muhammad's Model of Interreligious Dialogue Based on Research on the Letter to the Christians
}

\author{
Model medreligioznega dialoga preroka \\ Mohameda na temelju študije Pisma kristjanom
}

\begin{abstract}
Violence and extremism are among the most important topics in current research on religion and interreligious studies. The New World Order and the global peace, justice, and ethics cannot be understood without accounting for the role of religion and religious organizations, and among the topics dealing with religion is the matter of violence done by the excuse of religion's orders. There is increasing research looking at and beyond religious causes of violence, as well as hope that religion could offer genuinely effective tools to control violence. As the best example of peaceful negotiations among Muslims and Christians, this article presents one of the important Islamic proofs narrated by Prophet Muhammad (S), called "The promise of Muhammad to the Christians till the end of the World", and the impact of interreligious and intercultural role on peace and conflict resolution, as well as the role of global ethics. This letter, per se, and its content which in numerous key points strengthens the ties between Christians and Muslims, has not only been accepted and well documented among both Shi'a and Sunnites but is also widely quoted and referred to in Christian sources. Surely this letter is invalidating the point on the extremist crimes committed in the name of Islam.
\end{abstract}

Key words: Muhammad, Promise, Interreligious Dialogue, Christians, model

Povzetek: Nasilje in ekstremizem sta dve izmed najpomembnejših tematik v trenutnih raziskavah o religiji in medreligijskem študiju. Novega svetovnega reda, globalnega miru, pravičnosti in etike ne moremo razumeti brez vloge religije in religioznih organizacij, med temami, ki se ukvarjajo z religijo, pa je vprašanje nasilja, do katerega prihaja $\mathrm{v}$ imenu religioznega reda. Vedno več je raziskav, ki se ukvarjajo z religioznimi in drugimi vzroki za nasilje, vznika pa tudi upanje, da bi religija lahko ponudila resnično učinkovita orodja za nadzor nasilja. Kot najboljši primer mirnega pogajanja med muslimani in kristjani članek poudari pomembne islamske dokaze, podane po preroku Mohamedu (S), z naslovom "Mohamedova obljuba kristjanom do konca sveta« ter vpliv medreligiozne in medkulturne vloge miru in razreševanja konfliktov pa tudi vloge globalne etike. To pismo samo po sebi in njegova vsebina, ki v mnogih točkah krepi vezi med kristjani in muslimani, nista bila zgolj sprejeta in dokumentirana med šiiti in suniti, ampak tudi večkrat navajana v krščanskih virih. Pismo seveda izničuje namene ekstremističnih zločinov, storjenih v imenu islama.

Ključne besede: Mohamed, obljuba, medreligiozni dialog, krščanstvo, model 


\section{Introduction}

- No peace among the nations without peace among the religions.

- No peace among the religions without dialogue between the religions.

- No dialogue between the religions without investigation of the foundations of the religions. (Küng 2007)

The history of the past decades contains many examples of human suffering and conflict that may fairly be laid at the feet of certain religious people and their understanding of how religion plays a role in their lives. And yet, religion cannot be avoided in any attempts to pursue peace and social justice among the people of the earth. Religion has failed to disappear as predicted by Marx, Freud, Nietzsche or any of the other Enlightenment theorists who tended to view it as a crutch that would be thrown away as scientific knowledge progressed. Between just the two major religions we are considering in this article, more than four billion people continue to orient their lives (at varying degrees of depth and commitment) around the meaning they find in Christ or the Qur'an.

In this stream, as noted, Islam and Christianity are two of the most numerous and the most influential of the world religions today. They share many points in common as religions. Most important of all they trace their lineage to one common ancestor, Abraham, who is the Divine Patriarch of the religions, named after him as the Abrahamic religions. Knowing this, for any religious person among these two, it is a must to endeavour for approximation of them more and more, due to the current world's situation filled with challenge and tension. Based on this mentality, having attracted scholars in the current situation, there are important reasons for Christian theology to deal with Islam. They have something to do with striving for insight and with the belief that Christianity and Islam have something to say to each other. Relevant issues are the conception of God, the God-man relationship and the formation of religious identity. Dialogue, or peaceful negotiation, is the path prescribed by Islam. Islam is based on the principle of dawah (invitation) which is another name for peaceful negotiation manifesting that violence is totally forbidden in Islam. The Prophet of Islam started His mission which was to communicate his ideology to people by talking to them, listening to their objections and trying to convince them of his viewpoint by means of arguments. In a 
situation where many people are under the impression that Muslims are close-minded and unwilling to engage in discussion with people of other religions, dialogue and effective communication, based on tolerance, respect and love, are very constructive; this is while the holy Qur'an offers very clear guidelines and encouragement for Muslims to engage in an interreligious dialogue.

So, as a conflict resolution, for Christians and Muslims in particular, it would seem that there is much room and much need for this kind of dialogue to come to a better mutual understanding and appreciation, as demonstrated in Küng's theory about starting the process of dialogue from a "Global Ethic" point of view or from the mutual concern for social justice and the promotion of peace, because that would allow the dialogue to occur between the two religions on many levels. Peace among religions must start with an exploration of the common ground that already exists between them in matters of ethics: the establishment of a Global Ethic. Küng's argument for the need and the nature of a global ethic represent the minimal starting point of peaceful coexistence between cultures in an age of global awareness.

Before getting down to analyse different parts of the letter, there is a need to shed light on some related terms.

\subsection{Religion and Globalization}

In the conditions of the modern process of globalization, we have become much closer to each other. And particularly due to this development, the dialogue between nations, cultures, and religions is becoming more significant. By developing this dialogue, by supporting it, we can facilitate the definition of the sources serving to create terrorism, and, by doing this, we can destroy its very roots. Unfortunately, today, in some cases, terrorism hides behind religion and different spiritual developments. Nevertheless, it should not deceive us into diverting our attention from its actual meaning. There was a period when terrorism tried to obscure its real intentions by using beautiful slogans granted to humankind by the great French Revolution. The commissars implementing »the red terror« (Tecan, 2010) into life were executing this under the flags of communist ideology. Today, the terrorist forces, in order to achieve their provocative political targets, 
are using values that are sacred to all of us and are trying to justify terror to protect the interests of certain groups. While hiding under the cover of various religions, terrorism very skillfully tries to hide its destructive purposes. No cover, no excuse or pretence should mislead us, since one can easily disclose the real face of terrorism under all false covers.

\subsection{Islam and faith-based terrorism}

In his response to Huntington's "clash of civilizations « article (1993), Edward Said (2001) replacing the term with »Clash of Ignorance« argued that not only political leaders, but even academics can fall into the trap of simplification by basing their arguments on a perception of static, rather than dynamic relations between social and religious groups. He points out that the use of labels for groups, rather than groups themselves, is generating factors of conflict. According to him, the political and academic discourse on religious identities that distinguishes between »the West « and »Islam» promotes and amplifies conflict. (Saied 2001)

The escalation of violence carried out in the name of Islam should be attributed to a combination of factors where contextual variables, individual psychologies and opportunity structures in a society are central (Hafez 2003).

Looking at the entire processes rather than examining individual factors, ideas or actors appears to be more productive in capturing the shifting role of religion, band of Islam more specifically, in the current challenges of conflict and terrorism that the international community faces.

\subsection{Islamic Views on Peace and Violence}

Contrary to stereotypes about Islam, it advocates numerous nonviolent and peacebuilding values and expects Muslims to live by them. These values are supported by the Qur'an and the Hadith (the Prophet's sayings). One of these values is the duty to pursue justice (Qur'an 5:8). Another is the necessity of doing well by struggling against oppression and helping those in need. The third such value is that all humans are God's creation, have sacred lives, and thus are all equal (7:11). Islam grants no special privileges based on race, ethnicity, or tribal affiliation. Moreover, all 
Muslims are to respect and preserve human life (5:32). Islam also calls for the quest for peace, which is a state of physical, mental, spiritual, and social harmony (5:64). Other verses stress the importance of tolerance and kindness to other people (16:90). Looking at the life of the Prophet, one notes his use of nonviolent methods to resist those who persecuted him; the Prophet never resorted to violence or force. Peacemaking and negotiation are considered more effective than aggression and violent confrontation. In fact, the Arabic meaning of the word Islam itself connotes peace. Another virtue in Islam is forgiveness (23:96). Muslims are urged to live in harmony and peace with all fellow humans.

\section{The Letter (the Promise of Muhammad [S] to Christians)}

There are three versions of the letter, all written in the same spirit of peaceful coexistence within. The first and the second ones are very similar to each other, almost the same, but in translation there are a few differences. The third, shorter one, narrated by Sunni references, also contains the same elements. In the following sections we will describe all three of them.

\subsection{The Letter in Makatib al-Rasul (Letters of the Prophet)}

In Makatib al-Rasoul, translated as "Letters of the Prophet«, a well documented Shi'a book, famous for the letters sent to Sultans, Kings and important personalities of the time, compiled by late Ayatollah Ahmadi Miyanaji (1926-2000), ${ }^{1}$ a letter is narrated by the holy prophet of Islam (s) to the (Nestorian) Christians of St. Catharine in the north of Egypt. This letter which was verbalized by Prophet Muhammad (s) and written down by Imam Ali (a) ${ }^{2}$ in the month of Muharram, in the year 624 (A.D. or the $3^{\text {rd }}$ year A.H.), contains important notions addressing almost all Christians and showing affection and friendship. The letter is as follows:

1 Makātīb al-rasūl (لوسرلابيتاكم) is a book by Ayatollah Ahmadi Miyanaji, consisting of the letters and written documents ascribed to the Holy Prophet (s). Apparently, the idea for such a book came to the author's mind as he was amending a book by al-Fayd al-Kashani, known as Ma'adin al-hikma fi makatib al-a'imma.

2 The first infallible Imam of Shi'a Muslims and the fourth caliph in Sunnite perspective. 
In the Name of God, the Compassionate the Merciful. This is a covenant from Muhammad bin Abdullah, the Messenger of God, to all Christians. I write this letter to be a proof after me indicating that Allah is Almighty and All-Wise. This is a covenant to all Christians in east and west, Arab and non-Arab, known and unknown. Do not break this covenant, or it would be the violation from the covenant of God and mockery to the allegiance of God. If you break it, you will be cursed by Him; no difference that you are a governor, a believer or a Muslim. All the rights which belong to me, my people and my relatives, are alike for Christians. They are my citizens and "the people of the dhimma14«. We prohibit any kind of bothering and annoying them [...] no bishop is enforced to discard his Episcopal position, no monk is needed to abandon his position. Those who are in Monastery can stay there and those who are in trip can come back. No church and no business place of the Christian must be destroyed and no property (confiscated) or use in building the mosques, if one violate it, had certainly broken God's covenant and stood against the holy Prophet (s); we do not want any ransom (Jeziah) or reparation from monks and bishops. Wherever they are, they have my support. In desert or faraway land, in east or west, in north or south, they are under my covenant and promise and all devils are away from them. Anyone from them who are in mountains or holy places worshiping God have my support. There is no tax or Zakat for their crops and harvests [...] do not dispute them but with good polemics [...] Whoever violates this covenant and acts against it undoubtedly has violated the covenant of God and His prophet [...] till when this world is alive must not violate it till the end of the world.

\subsection{English Translation of the Letter by Anton F. Haddad (1902, retrieved 2018)}

Another translation can be found in John Andrew Morrow's book The Covenants of the Prophet Muhammad with the Christians of the World (2013). To find different translations and interpretations, the references in Further Reading section can be found at the end of this paper (End Notes of this article). 
English translation of the letter by Anton F. Haddad (1902):

This is a letter which was issued by Mohammed, Ibn Abdullah, the Messenger, the Prophet, and the Faithful, who is sent to all the people as a trust on the part of God to all His creatures, that they may have no plea against God hereafter. Verily God is Omnipotent, the Wise. This letter is directed to the embracers of Islam, as a covenant given to the followers of Jesus the Nazarene in the East and West, the far and near, the Arabs and foreigners, the known and the unknown.

This letter contains the oath given unto them, and he who disobeys that which is therein will be considered a disbeliever and a transgressor to that whereunto he is commanded. He will be regarded as one who has corrupted the oath of God, disbelieved His Testament, rejected His Authority, despised His Religion, and made himself deserving of His Curse, whether he is a Sultan or any other believer of Islam. Whenever Christian monks, devotees and pilgrims gather together, whether in a mountain or valley, or den, or frequented place, or plain, or church, or in houses of worship, verily we are [at the] back of them and shall protect them, and their properties and their morals, by Myself, by My Friends and by My Assistants, for they are of My Subjects and under My Protection.

I shall exempt them from that which may disturb them; of the burdens which are paid by others as an oath of allegiance. They must not give anything of their income but that which pleases them - they must not be offended, or disturbed, or coerced or compelled. Their judges should not be changed or prevented from accomplishing their offices, nor the monks disturbed in exercising their religious order, or the people of seclusion be stopped from dwelling in their cells.

No one is allowed to plunder these Christians, or destroy or spoil any of their churches, or houses of worship, or take any of the things contained within these houses and bring it to the houses of Islam. And he, who takes away anything therefrom, will be one 
who has corrupted the oath of God, and, in truth, disobeyed His Messenger.

Jizya should not be put upon their judges, monks, and those whose occupation is the worship of God; nor is any other thing to be taken from them, whether it be a fine, a tax or any unjust right. Verily I shall keep their compact, wherever they may be, in the sea or on the land, in the East or West, in the North or South, for they are under My Protection and the testament of My Safety, against all things which they abhor.

No taxes or tithes should be received from those who devote themselves to the worship of God in the mountains, or from those who cultivate the Holy Lands. No one has the right to interfere with their affairs, or bring any action against them. Verily this is for aught else and not for them; rather, in the seasons of crops, they should be given a Kadah for each Ardab of wheat (about five bushels and a half) as provision for them, and no one has the right to say to them "this is too much", or ask them to pay any tax.

As to those who possess properties, the wealthy and merchants, the poll-tax to be taken from them must not exceed twelve drachmas a head per year.

They shall not be imposed upon by anyone to undertake a journey, or to be forced to go to wars or to carry arms; for the Muslims have to fight for them. Do no dispute or argue with them, but deal according to the verse recorded in the Quran, to wit: »Do not dispute or argue with the People of the Book but in that which is best" (29:46). Thus they will live favoured and protected from everything which may offend them by the Callers to religion (Islam), wherever they may be and in any place they may dwell.

Should any Christian woman be married to a Muslim, such marriage must not take place except after her consent, and she must not be prevented from going to her church for prayer. Their churches must be honoured and they must not be withheld from building churches or repairing convents. 
They must not be forced to carry arms or stones; but the Muslims must protect them and defend them against others. It is positively incumbent upon every one of the follower of Islam not to contradict or disobey this oath until the Day of Resurrection and the end of the world.

According to the Sunnites narration, the same letter is recounted under the title »the Promise to St. Catherine». In $628 \mathrm{AD}$, a delegation from St. Catherine's Monastery came to Prophet Muhammad (s) and requested his protection. He responded by granting them a charter of rights, which is reproduced below in its entirety. St. Catherine's Monastery is located at the foot of Mt. Sinai and is the world's oldest monastery. It possesses a huge collection of Christian manuscripts, second only to the Vatican, and is a world heritage site. It also boasts the oldest collection of Christian icons. It is a treasure house of Christian history that has remained safe for 1400 years under Muslim protection.

\subsection{The Promise to St. Catherine in Shorter Text}

This is a message from Muhammad ibn Abdullah, as a covenant to those who adopt Christianity, near and far, we are with them. Verily I, the servants, the helpers, and my followers defend them, because Christians are my citizens; and by Allah! I hold out against anything that displeases them. No compulsion is to be on them. Neither are their judges to be removed from their jobs nor their monks from their monasteries. No one is to destroy a house of their religion, to damage it, or to carry anything from it to the Muslims' houses. Should anyone take any of these, he would spoil God's covenant and disobey His Prophet. Verily, they are my allies and have my secure charter against all that they hate. No one is to force them to travel or to oblige them to fight. The Muslims are to fight for them. If a female Christian is married to a Muslim, it is not to take place without her approval. She is not to be prevented from visiting her church to pray. Their churches are to be respected. They are neither to be prevented from repairing them nor the sacredness of their covenants. No one of the nation (Muslims) is to disobey the covenant till the Last Day (end of the world). 
This letter that is also famous for being the "Peace Manifestation of Muslims" clearly shows the guidelines and it shows that the prophet issued the letter as if had foreseen today's opposition against Christians in the name of religion and Islam. Moreover, the first and the final sentences of these two letters are critically important. They make the promise eternal and universal. Muhammad (s) asserts that Muslims are with Christians near and far straight away rejecting any future attempts to limit the promise to St. Catherine alone. By ordering Muslims to obey it until the Day of Judgment the charter again undermines any future attempts to revoke the privileges. These rights are inalienable. Muhammad (s) declared Christians, all of them, his allies and he equated ill treatment of Christians with violating God's covenant.

A remarkable aspect of the charter is that it imposes no conditions on Christians for enjoying its privileges. It is enough that they are Christians. They are not required to alter their beliefs, they do not have to make any payments and they do not have any obligations. This is a charter of rights without any duties!

The document is not a modern human rights treaty but even though it was penned in 628 A.D. it clearly protects the right to property, freedom of religion, freedom of work, and security of the person. (Bhala, 2011)

The letter, though in three unisonous versions, denotes the following points.

- The eternity of the covenant based on the last sentence.

- The universality of the covenant to all Christians in east, west, north, and south.

- The covenant contains a promise and binds the content to obedience, therefore any transgressors would be deemed to be under the wrath of God.

- The evangelism and warning spirit of the covenant. All the lines either give good guidelines or warn the violator of the displeasure of God and His prophet.

- Irrevocability of the letter so that the letter is neither abrogated nor excusable. 
- The principle of peaceful coexistence and the prohibition of persecution of Christians in Islamic or non-Islamic lands.

- Faith and social security and the principle of brotherhood.

- Special respect for religious leaders and specific social immunity for the clerics and priests who lead church or monastery.

- Honour to the sacred places of Christians, business places and their houses.

- Goodly exhortation and dispute. i.e., even if there are disagreements, solve the problems with good argumentation. This note is based on the Qur'anic verse: »Do not dispute or argue with the People of the Book but in that which are best.«(29:46)

- The permissibility of interreligious marriage and freedom of belief at home.

- Interreligious union and coalition.

- Emphasis on Citizenship and integration of Christians in Islamic countries.

According to these notes, one can easily perceive the entity and the fake nature of the extremists' acts - massacres and destruction of churches in Islamic countries - performed today in the name of religion and Islam. The theme of the letter is addressed in a way as if prophet Muhammad (S) had predicted the current world situation.

In the following part, some Qur'anic verses will be noted which clearly depict the origin and principals of the letter and also the nature of the Islamic perspective on coexistence with other religions.

\section{Qur'anic Verses about Interreligious and Intercultural Unity}

According to the main teachings of Islam and Qur'an, freedom of religion, equality, justice, rationality, being pious and loving other human beings are mentioned in the verses of Qur'an, some of which are stated below. They all need to be contemplated.

- You who believe! Enter into peace and all and do not follow into the footsteps of Satan for he is your open enemy. (2:208)

- When Allah said, »O Jesus, I shall take your soul, and I shall raise you up toward Myself, and I shall clear you of [the calumnies of] the faithless, and I shall set those who follow you above the faithless until 
the Day of Resurrection. Then to Me will be your return, whereat I will judge between you concerning that about which you used to differ." (3:55)

- Had not Allah repulsed the people from one another, ruin would have befallen the monasteries, churches, synagogues and mosques in which Allah's Name is mentioned greatly. Allah will surely help those who help Him. Indeed Allah is all-strong, all-mighty. (22:40)

- Say, "We have faith in Allah, and in what has been sent down to us, and what was sent down to Abraham, Ishmael, Isaac, Jacob and the Tribes, and that which Moses and Jesus were given, and the prophets, from their Lord. We make no distinction between any of them, and to Him do we submit." (3:84)

- The Messenger believes in what has been sent down to him from his Lord, and [so do] believers; everyone believes in God and His angels, His books and His messengers. We do not differentiate between any of His messengers. They say, „We have heard and obey; [we beg] Your pardon, our Lord! Toward You lies the Goal.«(2:285-286)

- Indeed the faithful, the Jews, the Christians, and the Sabaeans - those of them who have faith in Allah and the Last Day and act righteously they shall have their reward near their Lord, and they will have no fear, nor will they grieve. (2:62)

- Mankind! Indeed We created you from a male and a female, and made you nations and tribes that you may identify yourselves with one another. Indeed the noblest of you in the sight of Allah is the most God wary among you. Indeed Allah is all-knowing, all-aware. (49:13)

- Muslims! Be ever steadfast in upholding equity without partiality, bearing witness to the truth for the sake of ALLAH, even though it is against your own selves or your parents and kinsfolk. Whether the person concerned is rich or poor, ALLAH's claim takes precedence over both. Do not follow personal inclination, lest you not be just. And if you will try to distort or refuse to testify, indeed ALLAH is aware of all that you do! (4:135)

- For you, your religion, and for me, my religion. (109:6)

- There must not be any compulsion in religion[.] (2:256)

- O Muslims! Stand out firmly in your devotion to ALLAH as witness to fair dealing, and let not the ill will of anyone lead you into the sin of deviating from justice. Be just and impartial: this is closest to being 
God-conscious. And remain conscious of ALLAH: verily, ALLAH is aware of all that you do. (5:8)

- O You who believe! Enter absolutely into peace (Islam). Do not follow in the footsteps of satan. He is an outright enemy to you. (2:208)

- You cannot guide those you would like to but God guides those He wills. He has best knowledge of the guided. (28:56)

For more elaborations and more verses, refer to my article Islamic Approaches for Developing Muslim-Christian Interfaith Dialogue and Communications. (Golestani 2012)

\section{Conclusion}

If we look back at the very emergence of Islam, it is clear that the invitation toward the new religion by the Holy Prophet of Islam and His Infallible Ahlulbayt (Prophet Muhammad's Progeny - PBUT) had never resorted to any kind of force, violence or any other type of uncivilized matters; quite opposite, scientific discussions, negotiations and agreements were the only prescribed ways of dealing with non-Muslims. Following this method, many Shi'a scholars in the history took the way of dialogue as the only constructive method for establishing peace and justice, and history also shows that the most constructive and influential services to the religiosity had always been done by the peace makers and the people of dialogue. Believers and religious communities, based on their faith in God, have a specific role to play in society, on an equal footing with other citizens; moreover, believers are called to cooperate in the search for common good, on the basis of a sound relation between faith and reason. It is necessary for Christians and Muslims as well as all believers and persons of good will to cooperate in addressing modern challenges, promoting moral values, justice and peace and protecting the family, environment and natural resources. Faith, by its very nature, requires freedom. Therefore, religious freedom, as a right inherent to human dignity, must always be respected by individuals, social actors and the state. The cultural and historical background of each society which is not in contradiction with human dignity should be taken into consideration in applying this fundamental principle. Besides, religion has an inherent social dimension that the state has the obligation to respect; therefore, also in the interest of society, it cannot be confined to private sphere. 
Qur'an, as mentioned before, very strongly insists on the unity of the Divine religions, Books and their followers. Qur'an proclaims that the origin of the revealed Books and Holy scriptures is one before God, the Almighty, and that origin is called Ummol Kitab (Mother of the Books) or Luhe Mahfudh, namely, the Preserved Tablet which only God and His Messengers are aware of.

Let's complete the article with a promising verse and a declaration issued by International Institute for Peace and Religions (IIPR) as well as ViQo Circle $^{3}$ Members in 2018.

Give good news to My servant (17) who listen to the word (of Allah) and follow the best (sense) of it. They are the ones whom Allah has guided, and it is they who possess intellect (Qur'an-39:17-18).

\section{Declaration}

The members of the ViQo-Circle declare the following:

In a world of dramatic change with rapid technological advancement, including the influence of communications media greater than ever before, we believe that the fundamental questions of mankind need to be addressed again. Peace of mankind depends on guiding the processes of change so that they will be changes for the better rather than for the worse. But if we are to know what changes are "for the better", we must understand what the good is. And this raises fundamental questions: What is the good for man? What is justice? What is peace? What is freedom? It is not possible to remain neutral towards these questions. Every attempt at promoting the welfare of our world implies answers to them.

We firmly believe that true understanding of religion is indispensable in the search for truth, goodness, and justice and that without it there will be no peace. We hold that all things have been created

3 The Vienna-Qom Circle for Catholic-Shi'a Dialogue on Religion, Philosophy and Political Theory (ViQo Circle) is a group of scholars founded by Sheikh Dr. Taher Amini Golestani of Qom, Iran, and Dr. Christian Machek of Vienna, Austria. 
by the all-powerful and all-wise God, and that the objective truth in the world which we call "nature« is therefore related to the reason of God. Humankind can find in nature a so-called »natural law» that helps them to see what is truly good. We call on scholars in all fields to help develop understanding of this ethical code of natural law.

Peaceful coexistence of nations cannot prevail unless religious and political leaders stand together in their effort to contribute to the search for truth and the fostering of the virtues - the necessary and constant education of mankind. This implies the understanding that human beings have obligations, duties, and rights that derive from the nature that God has given them. They are obliged to work together for the common good, to defend innocent life and human dignity. They must allow one another the right to such goods as self-preservation, procreation, the increase of knowledge, participation in social life, and especially the worship God.

We believe that true peace cannot be established unless politics can be reconnected to morality and faith in God. The wellbeing of society and the state strongly depends on the active role of religion within them. We therefore appeal to political leaders to respect the contribution of religion to the common good. And we call on the religious communities to develop mutual understanding, deeper insight into the fundamental ethical and social questions that mankind faces and to develop common standpoints where possible.

\section{References:}

Amini Golestani, Sheikh Taher. 2016. Islamic Approaches for Developing MuslimChristian Interfaith Dialogue and Communications, Ethica Themen Journal, in cooperation ViQo Circle, Institut für Religion und Frieden, as an official publication of the Republic of Austria.

Bhala, Raj. 2011. Understanding Islamic Law, Shri'a, ISBN978.1.4224-1748-5, University of Kansas, School of Law.
Haddad, Anton F. 1902. The Oath of the Prophet Mohammed to the Followers of the Nazarene. Bahai-Library.com. New York, NY: Board of Counsel, 1902. Retrieved Sep 2, 2018.

Khosrokhavar, F. 2005. Suicide Bombers: Allah's New Martyrs. London: Pluto Press.

Levent Tezcan. 2010. Religion and Control of Violence. Tilburg: Tilburg University, Department of Culture Studies. 
Mandaville, P. 2007. Global Political Islam. London and New York, NY: Routledge.

Moghadam, A. 2009. 'Motives for Martyrdom'. International Security 33 (3): 46-78.

Morrow, John Andrew. 2013. The Covenants of the Prophet Muhammad with the Christians of the World. Kettering, OH: Angelico Press/Sophia Perennis.
Said, E. 2001. The Clash of Ignorance. The Nation 273: 11-14.

Vryonis, S. 1981. The History of the Greek Patriarchate of Jerusalem as Reflected in Codex Patriarchus No. 428, 1517 1805. Byzantine and Modern Greek Studies 7: 29-53.

\section{Further Reading References for the Letter of Muhammad (s)}

\section{Primary sources}

Amarah, Muhammad. 2002. al-Islam wa al-akhar. Maktabah al-Sharq al-Dawliyyah.

Thévenot, Jean de. 1665. Relation d'un voyage fait au Levant. Paris: L. Billaine.

Pococke, Richard. 1743. 'Chapter XIV: The Patent of Mahomet, which he granted to the Monks of Mount Sinai; and to Christians in General.' Description of the East. Vol. 1, 268-70.

Arundale, Francis. 1837. Illustrations of Jerusalem and Mount Sinai. London: Henry Colburn.

\section{Secondary sources}

Atiya, Aziz Suryal. 1955. The Arabic

Manuscripts of Mount Sinai: A

Handlist of the Arabic Manuscripts

and Scrolls Microfilmed at the Library

of the Monastery of St. Catherine,

Mount Sinai. Baltimore: Johns

Hopkins Press.

- - -. 1952. The Monastery of St. Catherine and the Mount Sinai Expedition.

Proceedings of the American Philosophical Society 96.5: 578-86.

Hobbs, J. 1995. Mount Sinai. Austin: University of Texas Press.

Lafontaine-Dosogne, Jacqueline. 1996. Le Monastère du Sinaï: creuset de culture chrétiene (Xe-XIIIe siècle). In East and West in the Crusader states. Context Contacts - Confrontations. Acta of the congress held at Hernen Castle in May, ed. Krijnie Ciggaar, Adelbert Davids, Herman Teule. Vol 1. Louvain: Peeters.
Davenport, John. 1869. An Apology for Mohammed and the Koran. London: J. Davy and Sons.

Affagart, Greffin. 1902. IN: J. Chavanon, ed. Relation de Terre Sainte. Paris: V. Lecoffre. (archive.org)

Hobbs, Joseph J. 1995. Mount Sinai. Austin: University of Austin Press.

Morrow, John Andrew. 2013. The Covenants of the Prophet Muhammad with the Christians of the World. Tacoma, WA: Angelico Press / Sophia Perennis.

Manaphis, K. A., ed. 1990. Sinai: Treasures of the Monastery of Saint Catherine. Athens.

Mouton, Jean-Michel. 1998. Les musulmans à Sainte-Catherine au Moyen Âge. Le Sinai durant l'antiquité et le moyen âge. 4000 ans d'histoire pour un desert. Paris: Editions Errance.

Pelekanidis, S. M., P. C. Christou, Ch. Tsioumis, S. N. Kadas. 1974-1975. The Treasures of Mount Athos [Series A]: Illuminated manuscripts. Athens. A copy in the Simonopetra monastery,

Ratliff, Brandie. 2008. The monastery of Saint Catherine at Mount Sinai and the Christian communities of the Caliphate. Sinaiticus. The bulletin of the Saint Catherine Foundation (archived).

Sotiriou, G. and M. 1956-58. Icones du Mont Sinaï. 2 vols (plates and texts). Collection de L'Institut francais d'Athènes 100 and 102. Athens. 